\title{
“"Shakspeare, s'avançant”
}

\author{
Hiscock, Andrew
}

\section{Shakespeare}

\author{
DOI: \\ 10.1080/17450918.2017.1356864
}

Published: 01/12/2017

Peer reviewed version

Cyswllt i'r cyhoeddiad / Link to publication

Dyfyniad o'r fersiwn a gyhoeddwyd / Citation for published version (APA):

Hiscock, A. (2017). "Shakspeare, s'avançant": A Bard, the Nineteenth Century and a Tale of Two Cities' Theatres'. Shakespeare, 13(4), 333-50.

https://doi.org/10.1080/17450918.2017.1356864

\footnotetext{
Hawliau Cyffredinol / General rights

Copyright and moral rights for the publications made accessible in the public portal are retained by the authors and/or other copyright owners and it is a condition of accessing publications that users recognise and abide by the legal requirements associated with these rights.

- Users may download and print one copy of any publication from the public portal for the purpose of private study or research.

- You may not further distribute the material or use it for any profit-making activity or commercial gain

- You may freely distribute the URL identifying the publication in the public portal ?
}

Take down policy

If you believe that this document breaches copyright please contact us providing details, and we will remove access to the work immediately and investigate your claim. 


\title{
"Shakspeare, savançant": a bard, the nineteenth century
} and a tale of two cities' theatres

\author{
Andrew Hiscock ${ }^{*}$
}

School of English Literature, Bangor University/Marie Sklodowska-Curie Research

Fellow (Institut de Recherche sur la Renaissance, l'Age Classique et les Lumières,

Université Paul-Valéry, Montpellier III)

While much scholarship of the nineteenth century has been justly devoted to the Romantic veneration for Shakespeare, the elaborate stagings of his works and the professionalisation of Shakespeare studies during the course of the period, this article focuses upon Shakespeare himself onstage in the theatres of London and Paris. Many theatrical productions in both capitals offered scenes of characters reading, reciting and paraphrasing Shakespearean texts in dramatic, comic and/or burlesque settings, however a number offered the figure of the dramatist amongst the dramatis personae. Often drawing inspiration from Alexandre Duval's Shakespeare Amoureux (1804), both French and English dramatists exploited on the rising cultural capital of the Renaissance dramatist to have him directly intervene in dramatic intrigues and sometimes to assume the role of protagonist. This discussion will focus upon some of the ways in which Shakespeare was called upon to tread the boards of Parisian and London theatrical and musical stages in the period c. 1830-70.

* email: a.hiscock@bangor.ac.uk 
Keywords: reception, Duval, Coyne Sterling, George Sand, Somerset, Moncrieff, Rosier/de Leuven, Couturier

SEE, my lov'd Britons, see your Shakespeare rise,

An awfull ghost confess'd to human eyes! [...]

Untaught, unpractis'd, in a barbarous Age,

I found not, but created first the Stage.

And, if I drain'd no Greek or Latin store,

'Twas, that my own abundance gave me more. (Dryden, Troilus and Cressida $\left.1679: \mathrm{b}^{\mathrm{r}}\right)^{1}$

At the opening of John Dryden's Troilus and Cressida, or, Truth found too late (1679), the audience at the Duke's Theatre, London, was greeted with a "Prologue Spoken by Mr. Betterton, Representing the Ghost of Shakespear" from which the above extract is taken. In the 1670 s Dryden had already turned his attentions to making Antony and Cleopatra "fit" for the stage (as All for Love), as had Sir William Davenant, for example, with regard to Macbeth in the same decade-(Dryden, All for love; Davenant, 1674). However, for this rendering of Shakespeare's most bitter comedy, Dryden summoned up the spirit of the bard himself, interpreted by the leading actor of the age, Thomas Betterton (1635-1710). This is thought to be the earliest presentation of Shakespeare himself onstage and offers a key opportunity to examine how theis tradition of staging the early modern dramatist, a tradition seemingly initiated by Dryden, continued across the generations and was renewed for London and Parisian theatre audiences in the nineteenth century. ${ }^{2}$ 
Whereas that century has frequently been presented as a period of consolidation in the establishment of a national, nay international, poet, the present discussion seeks to nuance this account of Shakespearean reception, drawing attention to the multiple currents and, indeed, cross-currents of opinion available in Britain and France during the period. In addition, on further examination, it becomes increasingly apparent that an enduring critical appetite for identifying the seemingly irrepressible primacy of Shakespearean textual and cultural presence with the passage of years has yet to accommodate adequately a number of resisting readers and examples of resisting entertainments available to nineteenth-century audiences in both London and Paris.

\section{Shakespeare - the Spirit rises}

Seizing upon Dryden's initiative in 1679 , the convention of drawing a ghostly bard into a dramatic narrative was welcomed by other writers in the decades which followed Troilus and Cressida made "fit" by the Restoration poet laureate. Indeed, the introduction of this spectral figure, engaging variously in debates concerning aesthetic practice, theatrical taste cultures, political change and patriotic appeals would recur periodically throughout the eighteenth century (see Franssen 12ff). In Bevil Higgons' prologue to George Granville's The Jew of Venice (1701), for example, "the ghosts of

Shakespear and Dryden arise, $€$ Crown'd with 1 Lawrel", with the former declaring defiantly "This Play, ye Criticks, shall your Fury stand" (see Granville, n.p.-A4 Some four decades later, in the second act of Elizabeth Boyd's "ballad-opera" Don Formatted: Font: Italic Formatted: Font: Italic Formatted: Superscript Formatted: Superscript Sancho: or, the Students whim (1739), the audience could look forward to an even more elaborate tableau: "the Earth trembles, and the ghosts of Shakespear and Dryden rise as in Glory to a soft sweet Symphony" (Boyd $\mathrm{C}_{2}{ }^{\mathrm{r}}$ ). Strikingly, the eerie shadow of 
Shakespeare was not only given admission to the playhouses during the eighteenth century, but might also be discovered in prose fiction and journalistic accounts. Garrick's entertainments, both within and without the theatre, in the mid-eighteenth century invited audiences to render homage to the late bard and his creations. Elsewhere, in Henry Fielding's prose narrative A Journey from This World to the Next (1749), for example, a spectral Shakespeare, amongst other spirits, was once again encountered, but here as a rather abstracted resident of the Elysian Fields who seemed most concerned to deride one of his editors (and a notably estranged acquaintance of Fielding), namely Theobald (see Hiscock, “'O, Tom Thumb!”-2014:228-63). Although such a tradition of ghostly luminaries summoned from the hereafter was much less in evidence by the close of the century, there were some examples which still accommodated such expectations in the succeeding age. ${ }^{3}$ Across the Channel, for example, the celebrated novelist George Sand (1804-76) was also the author of a number of plays, and in the revolutionary year of 1848 , Le roi attend was an entertainment specifically designed for the opening of Paris's Théâtre de la République (formerly, the Comédie Française), marking a seemingly new, democratic dawning for the nation. ${ }^{4}$ Here, in Sand's short one-act play, we encounter a weary Molière confronted with the emergencies of an unfinished script and the imminent arrival of the king to view its performance:

Molière Le roi aura de l'indulgence.

Laforêt Les rois n'en ont point pour ce qui regarde leurs amusements.

(Sand 126 (sc. i) )5 
The agitation surrounding the entry of Louis XIV and the subsequent waning of the royal patience leads seemingly to a crisis of allegiance for the court dramatist: "Je suis un homme désespéré, un homme perdu, un homme mort! Ah! maudite soit l'heure que j'acceptai les commandements d'un roi" (Sand 133 (sc. ix)). ${ }^{6}$ From this state of anguish, a more profound questioning wracks Molière's mind which would have been very much to the taste of the revolutionary audience of 1848: "Qu'est-ce qu'un roi? Un homme qui a puissance de faire le bien, et c'est seulement quand il le fait qu'il se distingue des autres hommes" (Sand 135 (sc. ix)). ${ }^{7}$ It is at this point that Sand looks back to a well-established tradition of welcoming the spirits of literary figures onto the stage. Indeed, as the exhausted dramatist sinks into his slumbers:

[...] un nuage l'enveloppe lentement; un choeur de musique chante derrière le nuage. Quand le nuage se dissipe, on voit debout, autour de Molière endormi, les ombres des poètes antiques et modernes-: Plaute, Térence, Eschyle, Sophocle, Euripide, Shakspeare, Voltaire, Rousseau, Sedaine, Beaumarchais etc. La Muse du théâtre est au milieu d'eux, tout près de Molière. (Sand 135 (sc. ix) $)^{8}$

Here, in direct comparison with a number of eighteenth-century texts, Sand's Shakespeare (saluted in this plays as "grand tragique et grand philosophe") keeps company with both the ancients and moderns, and in Le roi attend the bard is on hand to pin his colours to the new revolutionary age:

Ces temps nouveaux sont remplis d'étranges événements. Toute la masse de la terre a chancelé comme une machine mal assurée, et des tempêtes se sont élevées [...] Quant à moi, je n'étais point de ceux qui supportent l'injustice avec un visage 
serein, et, si parfois j'ai ri comme Molière, j'avais l'âme et le visage sérieux. (Sand $138($ sc. x $))^{9}$

After the interventions of all the assembled spectral presences, Molière awakens from his highly charged slumbers with revolutionary sentiments coursing through his veins: "Je vois bien un roi, mais il ne s'appelle plus Louis XIV; il s'appelle le peuple! Le peuple souverain!" (Sand 141 (sc. xi)).10

Sand's short play thus caters very much to the tastes and needs of the revolutionary times for the opening of a new, people's theatre in the French capital; and it does so by drawing upon a now familiar tradition of representing the revered writer as revenant. However, as will become apparent, rather than turning to the vagaries of the afterlife, nineteenth-century theatres in both London and Paris would show themselves much more responsive to the representation of Stratford lives for the early modern dramatist than had hitherto been the case. Interestingly, in so doing, the theatres indicated that they would be adopting a trajectory already in evidence in a number of contemporaneous art forms during the period. In the eighteenth century, Garrick's theatrical tributes to Shakespeare on and offstage had been eager to explore the possibilities of staged tableaux in order to make available for the national poet a suitably hallowed space of public admiration. Such ritualised entertainment was not infrequently renewed on canvas by artists of the period, such as Gainsborough's (now lost) “Garrick with a bust of Shakespeare” (1766-9), John Lodge’s engraving "Mr Garrick delivering his Ode at Drury Lane Theatre on dedicating a building and erecting a statue to Shakespeare" (1769) or Robert Edge Pine's painting "Garrick speaking the Jubilee Ode" (exhibited 1782). Equally prevalent were tributes to the poet expressed on canvas 
or engraving in terms of a processional of characters, such as in the case of Thomas Stothard's "Shakespearean Characters" (1813). ${ }^{11}$

These precedents for Shakespearean representation continued to be taken up as the eighteenth century gave way to the new century by artists such as George Romney ("The infant Shakespeare attended by Nature and the Passions" (1791)), Henry Fuseli ("The infant Shakespeare between Tragedy and Comedy" (1805)) and Richard Westall ("Shakespeare between Tragedy and Comedy" (1825)). Thus, for decade upon decade, Shakespeare and his creations had been recreated on canvas in galleries and artists' showrooms in terms of allegorical and/or highly ritualised tableaux and these would prove to be highly influential paradigms for later generations of British dramatists when they sought how to figure forth Shakespeare the man onstage for collective admiration. ${ }^{12}$ Moreover, as Stanley Wells has demonstrated, the public display of the Chandos portrait at the National Portrait Gallery in 1856 did much to excite yet further interest in the mid-century for the figure of the dramatist himself (Wells $\underline{\text { Shakespeare For All Time }}$ $2003 \div 146)$.

Turning more specifically to imaginative textual accounts of the poet's life, Walter Savage Landor published in 1834 a fiction detailing the supposed circumstances surrounding the figure of Shakespeare-the-deer-poacher (see Gross 239). Elsewhere, Charles Armitage Brown's Shakespeare's Autobiographical Poems, being his Sonnets clearly developed: with his Character drawn chiefly from his Works (1838) invested fully in the belief that penetrating insights into the author himself might be made available by careful study of his published texts. More broadly, Sir Walter Scott's enormously popular novel Kenilworth (1821) constituted a major inspiration for the age in the attempt to recover versions of Shakespeare's life for greater scrutiny and had an wide- 
reaching influence on succeeding generations of writers and artists. ${ }^{13}$ Transporting his readers to a time when Elizabeth was "in the prime of womanhood" (Scott $167(\mathrm{ch} . \mathrm{xv}))^{14}$, Scott had the sovereign herself summon up the shadowy figure of the national poet as "that archknave Shakspeare [...] a plague on him, his toys come into my head when I should think of other matters" - this same figure is later described by Sussex as "a stout man at quarter-staff, and single falchion, though, I am told, a halting fellow" (Scott 192, 205 (ch. xvii)). Subsequently, Leicester accosts the bard himself, declaring, "thou has given my nephew, Philip Sidney, love-powder - he cannot sleep without thy Venus and Adonis under his pillow!" (Scott 198-9 (ch. xvii)). ${ }^{15}$ Interestingly, Scott's novel would be swiftly and variously translated onto the French stage in the shape of Alexandre Soumet's Emilia (1823) and the young Victor Hugo's Amy Robsart (1828), but neither work evinced much interest in Scott's minor character named Shakespeare. ${ }^{16}$ In later fictionalized prose accounts of his life, however, the bard is allowed to shuffle off altogether the cameo role Scott had attributed to him and assume fully the status of protagonist. Nathan Drake's Noontide Leisure; or, Sketches in Summer, outlines from Nature and Imagination, and including A Tale of the Days of Shakspere (1824), for example, sought to renew the account of Shakespeare's apparently adventure-ridden life (amongst other narratives) for the next generation of readers and his narrative is triggered by a riding accident in which the dramatist comes to the rescue of a literary admirer, Eustace Montchensey, who was coincidentally travelling to see him in Stratford (see Drake 1 $1:-24$ ). Robert Folkestone Williams, "endeavouring to exhibit something that approaches to the true character of the man", offered his readers The Youth of Shakspeare (1839) and transported them more immediately to Shakespeare's early Warwickshire years - "there is more of history in these pages than divers books 
purporting to be histories can boast of, and whenever they hold not Truth by the hand they tread as nigh upon her heels as may be" (Folkestone iv-v). Similarly minded nearly a decade later, Henry Curling's Shakspere; The Poet, the Lover, the Actor, the Man. A Romance (1848) evoked again a youthful bard who "had reached the age when the poetry of life begins to be felt [...] [and] is mixed up with the sterner ambitions of manhood" (Curling I: 4) ${ }^{17} \mathrm{~A}$ few years earlier across the Channel, the novelist Clémence Robert had conjured up in his William Shakspère (1844) the highly charged imagination of his protagonist who not only surrounded himself with books at his slumbers ("il me semble que leur approche me fait du bien, que mon esprit s'infiltre dans mon cerveau. Je rêve en vers, j'ai de charmantes visions"), but who takes his sources of inspiration into his waking life: "Eveillé je continue mes songes" (Robert 43, 44).18

Shakespeare: beyond the realm of mortals

As has become well documented in succeeding studies of Shakespearean scholarship, the renewed championing of both the dramatist and his work came to be one of the key commitments of the new generation of Romantic poets and writers across Europe as the age of Garrick and Fielding drew to a close and gave way to the new century. In his Discourse on the Manners of the Ancient Greeks Relative to the Subject of Love (1818), for example, Shelley argued that "Perhaps Shakespeare, from the variety and comprehension of his genius, is to be considered on the whole as the greatest individual mind of which we have specimens remaining" (Shelley-217-8). North of the border, the now internationally renowned novelist, Sir Walter Scott, confided in his journal of 1826, "The blockheads talk of my being like Shakespeare - not fit to tie his brogues" (Scott 252). The following year, in the extended preface to his epic drama Cromwell (1827), 
Victor Hugo hailed Shakespeare as "ce dieu du théâtre" (Hugo-181)9; and such fulsome enthusiastic tributes would continue throughout the century. In Britain, for example, in On Heroes, Hero-Worship and the Heroic in History (1840), Thomas Carlyle shadowed the steps of Shelley and hailed Shakespeare as "the greatest intellect who, in our recorded world, has left record of himself in the way of Literature"; and Matthew Arnold's bard, "out-topping knowledge", would continue to epitomise the child of nature so cherished of earlier generations of Romantic writers: "Self-school'd, selfscann'd, self-honour'd, self-secure" (Carlyle 96; Arnold, "Shakespeare"; 13$).{ }^{20}$

However, in imperial France in the opening years of the nineteenth century, Shakespeare himself presented, it appears, a particularly felicitious subject for the theatre. Alexandre-Vincent Pineux Duval (1767-1842) had pursued a number of careers which included acting in, managing and writing for theatres. Amongst his dozens of plays (both single-authored and collaborative), he composed the immensely popular and, from the perspective of this discussion, seminal work Shakespeare Amoureux (1804). Here, the hero is styled in the dramatis personae as "Poète tragique anglais". Nonetheless, as becomes apparent on further acquaintance with this dramatic narrative, like many contemporaries on both sides of the Channel, Duval had a most sketchy knowledge of Shakespeare's England and his writings. Most significantly, Duval found no necessity apparently for enquiring into the Elizabethan conditions of theatre-playing when preparing his one-act play. Drawing together the intrigue for Shakespeare Amoureux, Duval seems to have mined unreliable textual sources and translations as well as his own very lively interest in the genre of romance. Indeed, Shakespeare Amoureux is determined to have the bard domesticated in a dramatic narrative which strenuously obeys the unities of time, place and action, while paying little heed to any 
historical detail of the Tudor realm. ${ }^{21}$ In Duval's rendering, the focus of all romantic interest is la belle Clarence, the leading actress (sic) in Shakespeare's company, under whose spell both the dramatist and milord Wilson have quite clearly fallen:

Shakespeare [...] Quel démon me ramène dans cette maison ? [...] O

Shakespeare ! tu peins les passions et les faiblesses des hommes, et tu ne saurais t'en garantir! (Duval 3 (sc. $1 \underline{1} \underline{1}))^{22}$

Duval's short theatrical afterpiece is wholly taken up with Shakespeare's endeavours to gain access to his mistress in order to make an unequivocal declaration of love. Compelled to evade the hostile watch of the maid Anna, the dramatist secretes himself in closets and assumes disguises, but he eventually accomplishes his mission. The password into Clarence's chambers is "Richard III", which chimes aptly with the play that the actress is known to be rehearsing for performance. In a timely fashion, Shakespeare arrives to help her master her role and, in perhaps the most carefully crafted episode of the intrigue, he endeavours in metatheatric fashion to make known his affections while rehearsing the written text with his leading actress - however, this particular attempt fails to bear fruit: Shakespeare (à part) =- "Elle a pris la vérité pour une fiction" (Duval 23 (sc. viiz)). ${ }^{23}$ Nonetheless, in due course, Clarence yields to the romantic advances of the dramatist and Duval's final coup de théâtre recalls the tale of Shakespeare's own alleged retort to a rival for the attentions of a mistress:

$\begin{array}{ll}\text { Clarence } & \text { C'est Wilson ! } \\ \text { Une voix } & \text { Richard III. }\end{array}$

Shakespeare (s'avançant vivement à la croisée) Richard III est venu trop tard. Guillaume-le-Conquérant s'est emparé de la forteresse. 
After an initially mixed reception in 1804, the play became a European sensation. One of the leading French actors of the day, François Joseph Talma (1763-1826), took the play on tour in the French provinces, offering it as an afterpiece to performances of French adaptations of Shakespeare's tragedies. Subsequently, it became clear that the light comedy of Duval's playlet was very much to the taste of new audiences across the continent, being translated into all the major European languages as well as into several of the minor ones (see Franssen 42-3). However, it was not only the presentation of an impassioned, domesticated, bourgeois Shakespeare which was to inspire generations of dramatists throughout the nineteenth century. Duval's chief contribution in Shakespeare Amoureux would be to render the bard-as-protagonist in a dramatic narrative and to demonstrate that imaginative evocations of his life were worthy of theatrical treatment. As will become apparent, in a host of different ways, successive dramatists on both sides of the Channel would continue to acknowledge the potential of such subject matter and exploit it for both comic and romantic purposes for the stage.

\section{Shakespeare in London}

Perhaps because acquaintance with Shakespeare was re-directed rather than initiated by Romantic writings, there had long been the possibility of raising questions of difficulty or reservation in British (and more broadly anglophone) society with regard to the bard's works. In the eighteenth century, figures such as Fielding had already been querying whether all Shakespearean narratives, most especially the comic ones, could continue to triumph as the years lengthened since his passing: 
Many Characters in antient Plays (particularly in Shakespear) which were drawn from the Life, lose half their Beauty to us who are unacquainted with their Originals. Sir John Falstaff and his whole Gang must have given much more Entertainment to the Spectators of Queen Elizabeth's Days, than to a modern Audience. (Fielding zo03: 395; s. See also Hiscock, “'O, Tom Thumb!"'Hiscock 2014)

By the nineteenth century, contrary motions were still being played out at all levels of literate society. If, in 1845, a reviewer for the Northern Star might be found arguing that "The Englishman who has not read SHAKESPEARE may doubt his nationality; he is, at best, but half an Englishman, when ignorant of the works of his greatest countryman", a minor chord was swiftly struck for the periodical's readership: "yet, to how many millions has SHAKESPEARE been but little, if anything, more than a mere name. It is painful to reflect that thousands, nay, millions have lived and died, and never known him" (Murphy 132). Nonetheless, amongst those who did enjoy a much fuller acquaintance with the national poet, responses might still remain guarded in some respects. When the close friend of her youth, Ellen Nussey, asked Charlotte Brontë to recommend a reading programme, she received most fulsome-detailed advice from the novelist: "You ask me to recommend some books for your perusal [...] If you like poetry let it be first rate, Milton, Shakespeare, Thomson, Goldsmith, Pope (if you will though I don't admire him), Scott, Byron, Campbell, Wordsworth and Southey [...] don't be startled at the names of Shakespeare and Byron. Both these were great Men and their works are like themselves". However, Brontë also offered a recommendation which appeared to admit of no contradiction: "Omit the Comedies of Shakespeare" (Brontë 
130). By the mid-century, another writer for the Northern Star was contending that Hamlet was "more suitable for the closet than for the stage" (Murphy 150); and some thirty years later in 1878 , when funds were being sought for a lasting tribute to the bard, the Shakespeare Memorial Theatre, another celebrated novelist, Anthony Trollope exclaimed, “I don't care two pence for the Shakespeare Memorial [...] If there by any one who does not want more memorials than have been already given, it is Shakespeare!" (Trollope 392).

If condemnation of "bardolatry" has been most frequently associated in Britain with Shavian interventions at the close of the nienteenth century, it is evident that his responses form part of a much larger continuum in British society which sought often to nuance its responses, rather than express unalloyed joy at the widespread cultural investment in the creation of a national poet. One of the most dynamic expressions of print culture as the century unfolded was clearly reserved for the periodical, a form which was designed to engage a wide range of readerships. ${ }^{25}$ In the wake of the first Reform Act in 1832, the Westminster Review felt itself able to draw attention to the "respectable humbug" surrounding ongoing expressions of veneration for the bard (Schoch 3). However, such reservations had been voiced in a much more forthright manner in the previous year by a rather exercised contributor to the Literary Test who queried whether "instead of applying [his gifts] to the furtherance of knowledge and increase of happiness, [Shakespeare had] not somewhat preferred the advancement of his own individual interest, and tended to the perpetuation of ignorance and wretched inequality, by truckling to the vicious and distempered opinions of those who benefited by their continuance" (Murphy 115). Later, in the year of Victoria's accession, 1837, John Bell's Political Mirror remained unconvinced whether Shakespeare might be counted 
upon to support any political agenda in that age of such great social change and expectation: "In England we are in the habit of dividing politicians into Tories, Whigs, Radicals, and pretended Radicals. All these varieties may be found in Shakespeare although the specimens are not so ticketed and labelled" (Murphy 116).

As the illuminating collection Nineteenth-Century Shakespeare Burlesques edited by Stanley Wells highlighted, while versions of Shakespearean plays might be available for public consumption in licensed theatres in nineteenth-century London ${ }^{26}$, all kinds of comic sketches, burlettas and parodies were on offer for viewing at other performanance venues, such as Horace Amelius Lloyd's Rummio and Judy (1841), or later in the century broad comedies such as Hamlet! The Ravin' Prince of Denmark!! (1866) or A Thin Slice of Ham-Let! (c.1863)-(see Wells 1978). ${ }^{27}$ In the latter, the audience was invited once again to flex its memories of the $f$ Renaissance tragedy unfolding at Elsinore in order to enjoy the full pleasures of the intrigue now unfolding in doggerel verse:

King The court in mourning long enough has been,

And so you see, to make it all serene,

And keep his widow's royal sorrow down,

We have presented her with half a crown. (Wells, NineteenthCentury Shakespeare Burlesques 1978 - IV:4:53 (I.ip.1))

The entry of the protagonist promised no reprieve from such fare and, indeed, remained all of a piece with the broad brief for the evening's enjoyment in the theatre: "Dad's widow and his brother joined in one,_/_Makes me her nephew and my uncle's son!" (Wells 1978: IV4:57 (I.i1.1)). Such offerings in Victorian playhouses continued to be many and various as the century unfolded, and these included Macbeth Somewhat Removed 
from the Text of Shakespeare (1853), Perdita, or the Royal Milkmaid (1856), and Hamlet the Hysterical: A Delirium in Five Spasms!!! (1876) (see Taylor 138). As may be gathered from the titles alone, comic deflation, farce and bathos formed the stock-in-trade for such entertainments.

In a wide-ranging discussion of Shakespeare and nineteenth-century drama, David Francis Taylor has recently stressed that "Burlesque relentlessly exposes and erodes the fragile boundary between pathos and bathos on which a tragic text depends" (Taylor 139). If such works described above were by no means necessarily hostile to Shakespearean dramaturgy or to the Shakespearean cultural legacy as it was perceived at the time, they do indicate the breadth of response in evidence within British society when attention was turned to the works of the national poet. ${ }^{28}$ Nevertheless, with direct reference to the present discussion, Shakespeare himself was also being written onto the stage for nineteenth-century audiences. The first of these productions is thought to be Charles A. Somerset's Shakespeare's Early Days: An Historical Play, In Two Acts (1829), performed at Covent Garden with the Shakespearean actor Charles Kemble (1775-1854) in the title role (see Holland 138). Unlike a number of his contemporaries, Somerset did not draw directly upon Duval's Shakespeare Amoureux, but he did respond to Duval's initiative with enthusiasm that there was capital to be tapped in dramatising imagined scenes from the bard's life. Interestingly, in the first act of Somerset's short text, young Shakespeare is discovered in rural Warwickshire, subject once again to all the passion, tenderness and magnanimity that Romantic writers had repeatedly attributed to him in the preceding decades. Plaintively, the troubled pater familias John Shakespeare is heard to lament, "Is he not a loose, wild, hare-brained, young spendthrift?" (Somerset 3 (I.i.1.1.1)). In due course, the good-hearted, but now slumbering 
wastrel succumbs to a vision whereby a succession of Shakespearean characters is brought onstage to celebrate his great destiny:

Titania The son of Genius, who now slumbers there,

Hath from his youth been our especial care;

In him there dwells a great and mighty soul,

Which, to display itself without control,

Must quit these dull and rustic scenes of life,

And learn to glow, where, in the noble strife

Of emulation, he may be caress'd,

And the world's brightest genius stand confess'd!

(Somerset 4 (I.iil.2))

Interestingly, this tableau of a rustic idyll then gives way once again to the possibility of an interventionist, nay engagé bard. If the legend of Shakespeare as the poacher of Sir Thomas Lucy's deer is recalled by Somerset for his narrative, we find in this instance that the future national poet's sole ambition was to supply nourishment for a destitute shepherd and his "helpless babes":

Shakespeare I'll tell your worship. In a little cottage

By the wood-side, there dwells an humble shepherd;

A man, whose life, though spent in industry,

Hath ever been one tissue of misfortunes;

Disease, destroyed his flocks, and poverty

Hath, from a man of substance, brought him down

To abject wretchedness. (Somerset 6 (I.iil.2)) 
Like Sand decades later, Somerset briefly summons up the possibility of a bard with an acute sensitivity and social conscience in order to respond to the political turmoil and sedition in evidence in the world beyond the theatre - in this instance, the widespread economic distress of rural communities in early nineteenth-century Britain (see Worrall 13off). However, by the second act, hounded by Lucy's men, Shakespeare flies to London, and swiftly enjoys the patronage of Southampton and the comradeship of Tarleton and Burbage. Somerset now turns his taste for social critique to matters of a more literary cast - namely, the censorship of plays. George Colman remained the "examiner" of plays from 1824-36 and he would find himself broadly ridiculed in the shape of the pedantic Doctor Orthodox in Somerset's comedy. This censor initially refuses to license Shakespeare's script which violates the unities of time, place and action, but is eventually brought to heel at the sight of Southampton's signet ring. The action advances and in the wake of the news of the defeat of Armada, a jubilant Elizabeth finds time to look over this play script and its author, remarking "For in his eye there glows intelligence;_/Which heaven alone, and not scholastic lore,_/_Could have inspired" (Somerset 14 (H.iiiz.3)).29 Thus, winning the admiration of all ranks, Lucy's hounding of the poet comes to nothing and by the finale, once again, the dramatist has been permitted to claim the major role in a dramatic narrative as he had in Duval's. However, as we have seen, in Somerset's text, rather than Clarence, the principal woman focusing her attentions on Shakespeare is the queen herself and this motif would recur with great frequency in succeeding decades on both sides of the Channel.

In the following year, the prolific playwright William Thomas Moncrieff (17941857) produced Shakespeare's Festival; or, A New Comedy of Errors! (1830).30 Like a 
number of Garrick's productions in the eighteenth century and the tableaux envisaged in Sand's later Le Roi Attend, Moncrieff's play draws upon pageantry to offer due homage to a revered bard. In his short prefatory discussion, Moncrieff proposed that in this undertaking he sought to provoke "a harmless laugh at the follies of some of the madheaded commentators on the great Bard, and [to pay] a humble tribute of respect to his matchless merits" - and given the remit of his drama, these ambitions would seem to have been fulfilled (Moncrieff vii). As David Worrall has highlighted, both Moncrieff's and Somerset's plays “coincide with the attempt by the Shakespearean Club of Stratfordupon-Avon to celebrate Shakespeare's birth on a triennial basis" (Worrall 128). Indeed, Moncrieff himself submitted that "This little drama owes it birth to the late Shakespearean Festival at Stratford-upon-Avon" (Moncrieff v). The emphasis of the first half of this drama is indeed upon the rather grubby dimensions of the Shakespeare industry which was expanding rapidly in response to the proliferation of more associations of admirers, more touristic itineraries embracing sites linked to the bard, and greater commercial investment in a national poet. In Moncrieff's drama, the chairman of the Shakespeare Club at Stratford-upon-Avon, one Mr. Arden Shakespeare, presides over a meeting of the august assembly at the Falcon Inn: "Ah, Shakespeare was a divine creature - 'the paragon of animals'. I glory in being a votary of his; - I was christened after him - Shakespeare Arden - was born within a stone's throw of him the opposite butcher's shop, - called my daughter after one of his plays, - have all his relics, and know his works by heart" (Moncrieff 12-3 (I.i1.1.1)).

Rubbing his hands at the prospect of fortunes to be made in the welcome proffered to the arriving hordes, the proprietor of the Falcon Inn, Gaius, is heard to exclaim, "Rare times for Stratford,- would we had a Shakspeare born every year! [...] Hey! 
More guests coming! - if we continue to fill in this manner, there won't be a bed to be had for love nor money. Garrets fetch a rare high price, and cellars are not much lower; - my cellar will be lowered by it though. - This way, ladies and gentlemen" (Moncrieff 9 (I.i1.1)). One of the visiting tourists, the aptly named Glump, later exclaims, "Hum! I can't say I see any thing very remarkable in the house Shakespeare was born in; - any other man might have been born there for the matter of that - a very poor affair to come so many miles to see" (Moncrieff 10 (I.i1.1)). Interestingly, however, Moncrieff allows the broad humour deriding the Shakespeare Club and its associated commercial agents to give way to more romantic intrigue as the Chairman finds himself subsequently outwitted in the marrying off of his daughter Rosalind, and the whole entertainment is brought to a spectacular resolution with a re-enactment of a Stratford civic ceremonial: Moncrieff acknowledges that "the pageant which concludes this drama is nearly a facsimile of the procession" taking place in Stratford in 1830 (Moncrieff vii). Thus, the proceedings draw to a close in a suitably auspicious manner, familiar from eighteenthcentury spectacle, painterly representations and contemporaneous civic pageantry: "The whole terminating with a grand allegorical natal tableau; homage of the drama; Coronation of Shakespeare by the Tragic and Comic muses. - Fall of the Curtain" (Moncrieff $36($ (I.¥1.5) ).

Later in the decade, productions in 1838 such as The Queen's Command and Shakespeare and Burbage would be offered on the London stage, drawing some direct (if unacknowledged) inspiration from Duval's text. However, in the next decade, one J. Stirling Coyne was distinguishing himself by once again unveiling the bard onstage for London audiences. Coyne had already presented his public with a New Grand, Historical, Bombastical, Musical and Completely Illegitimate Tragedy to be called Richard 
III (1844) which was performed at the Adelphi Theatre. However, three years later, responding to the public outcry surrounding the proposed sale of Shakespeare's home, Coyne (duly signalled on the titlepage as the "Author of 'Binks the Bagman', 'Did you ever send your wife to Camberwell?' 'How to settle accounts with your Laundress!' \&c. \&c." (Coyne n.p.)) penned This House to be Sold; (The Property of William Shakspeare) Inquire Within. A Musical Extravaganza in One Act (1847) - again to be performed at the Adelphi Theatre. Here, the dramatist proved himself able to cater most attentively to audiences expecting variety entertainments at theatres like the Adelphi. Interestingly, examples of satirical critique, such as those found within Somerset's and Moncrieff's work, are in evidence throughout the play as is the concern to provide the broadest possible entertainment to the paying audience. Shakespeare (appearing in "William Shakespeare's dress") is included once again amongst the dramatis personae along with a very substantial number of his characters (notably, as will become clear, Othello in "Pink striped trousers, buff slippers, straw hat") and the familiar presence of allegorical figures - in this instance, the spirits of Tragedy, Comedy and Poetry.

The intrigue centres principally upon the profit-making venture of the mercantilist Mr Chatterton Chopkins, inheritor of his father's sizeable fortune made in the fishmonger business: "Well, he died, and I succeeded to his fortune and business, but having an ambition above common soles I cut the shop, and determined to distinguish myself in the world" (Coyne 4 (sc. $\left.\dot{1}_{1}\right)$ ). The venture in question is the newly acquired Shakespeare birthplace house (Chopkins - "'Twas in that grate then the fire of genius used to be kindled formerly" (Coyne 6 (sc._iiz)) and the commercial initiative is vigorously supported by his lawyer Grimshaw: "These are the dilapidated but heartstirring premises in which Shakespeare was entered upon the roll of life, and of which 
you have become the respected proprietor. [...] As your legal adviser I recommend you to exhibit it at so much a head" (Coyne 3-4 (sc. i표)).

Persuasively, Richard W. Schoch makes the telling point that

the play suggests, that shop assistants, clerks, petty tradesmen, and other members of the lower middle class were acquiring social aspirations. Disdainful of those who occupied the fringes of respectability, the middle class directed its prejudice most vehemently against the "gent". [...] As a classic cultural philistine, Chopkins desires Shakespeare instrumentally - that is, for his use-value only. He does not recognize Shakespeare because he does not have to. It is sufficient for his purposes that others do so. (Schoch 80-1)

However, rather than concentrating upon social critique, Coyne's play maintains a markedly extensive range of theatrical interests in keeping with the staple fare for the theatres in which such entertainments were on offer. Thus, broad comedy is sought out at every turn:

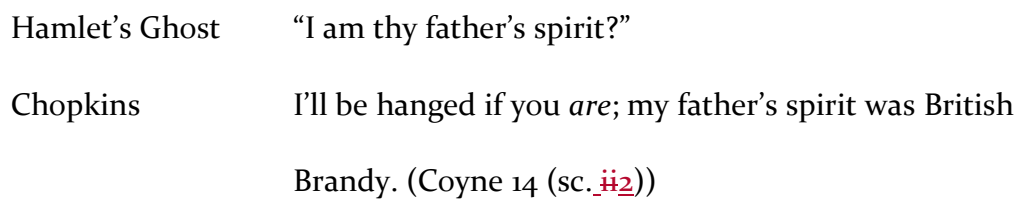

Elsewhere, space is duly made available, for example, for appeals and jingoistic interventions, familiar to audiences of the time:

Shakespeare $\quad$ True, my dress is not very modern, but 'tis of right English stuff - it wears well - feel it - there's pith and substance in it - none of your French second-hand frippery - (rises) 
'twas made "not for an age, but for all time".

(Coyne 9 (sc._iiz $)$ )

In addition, throughout the intrigue, the audience is left in no doubt that this is, as it claimed to be, "A Musical Extravaganza". Thus, opportunities present themselves for song in the opening scenes, but such opportunities are exploited most strikingly in the second phase of the narrative when Chopkins takes to his (or Shakespeare's former) bed for his first night of slumber in the bard's house. At this juncture Shakespeare himself is introduced onto the stage along with in due course a whole host of his creations (including Hamlet, Falstaff, Polonius, Shylock, Macbeth, Lady Macbeth, Romeo, Juliet, Master Slender, Mrs. Page and Mrs Ford), and a notable coup de théâtre in the action is the entrance of "Othello with a Banjo, and dressed partly as an Ethiopean Serenader, descend[ing] from the chimney". The latter duly proceeds to offer minstrel entertainment for those on- and off-stage:

Othello [singing] I once did lub Black Rose; oh! how she make me feel;

And den I turn my sentiments upon sweet Lucy Neal;

And den Miss Mary Blane - and about a dozen more -

But jealous Desdemona's always knocking at de door.

(Coyne 12 (sc._ii $\underline{2}))$

If Shakespeare becomes a, but not necessarily the, central character in the very diffuse spectacle of variétés which Coyne offered for mid nineteeth-century London audiences, strikingly the dramatist gave the opportunity for those paying to see the one-act entertainment to compare and contrast one successful businessman with another. In 
the company of his rather restive creations, Shakespeare is heard to retort, "I have put words in your mouths, and you have put bread in the mouths of thousands" (Coyne 13 (sc._ii2)). Nonetheless, as we have already witnessed at regular intervals in the dramatisation of Shakespeare onstage on both sides of the Channel, Coyne draws the theatrical extravagancies to a close with a visual feast of pageantry:

The back flat of Chamber sinks and discovers a grand tableau, consisting of SHAKSPEARE's characters grouped round the poet, who occupies a pedestal in the centre. The GENII of TRAGEDY and COMEDY kneel at the foot of the pedestal on either side. The SPIRIT OF POETRY descends and places a crown of laurel on his brow. Music as the Curtain descends on the Tableau.

(Coyne $16 \quad$ (sc. ii2))

Here, once again, it appears that the improbabilities of the dramatic action must be resolved ritualistically by the writer (see Nichols 24-32). In the instances of other dramatic works discussed here, it may be that the implication of the venerated poet in a succession of comic capers is thought to require a suitably sobering restorative either in the form of witty punchline (Duval) or in the form of spectacle. However, with This House to be Sold, Coyne appears to conceive of such a diverse, vaudeville form of entertainment on such a markedly crowded stage that the only way in which the oneact narrative can be brought to a close is through the sobering convention of the theatrical tableau. Nonetheless, offerings across the Channel at this time were seeking out quite different stagings for scenes from the life of the Elizabethan dramatist. 


\section{A Bard in Paris}

Indeed, one of the most striking contrasts with these British examples of satire, broad farce and popular spectacle would emerge on Paris's musical stage in the midnineteenth century. If it continued to be possible to witness Shakespeare in English or translation interpreted by leading actors of the time, such as Charles Kemble, Harriet Smithson and François Joseph Talma as the century unfolded in France, Shakespearean life was also adopted as a subject fit for performance on the operatic stage. In 1868 , the composer Charles Louis Ambroise Thomas (1811-96, known as Ambroise Thomas) wrote an opera of Hamlet ${ }_{32}^{31}$, and decades later in 1889 he also composed a ballet based on the intrigue of The Tempest. ${ }^{32}$ However, earlier in his career, drawing upon a libretto by Joseph Rosier and Adolphe de Leuven, Thomas composed Le Songe d'une nuit d'été which was performed at the Opéra-Comique in Paris on 20 April 1850. Ton Hoenselaars and Clara Calvo contend that "Le Songe d'une nuit d'été is important as the product of that rapid deification of Shakespeare in France during the early decades of the nineteenth century" (see Hoenselaars \&and Calvo 159, and also Sanders 100), and more than any other example of nineteenth-century dramatic narrative thus far discussed, this production invests much more unequivocally and in a sustained fashion in the idea of an heroic, passionate identity for the Renaissance dramatist which Hugo and his fellow Romantics had celebrated across Europe in the preceding decades. Equally interestingly, by this mid-point in the century, it is clear that on both sides of the Channel and for a wide range of audiences, Shakespeare had become a known, commodifiable and potentially lucrative form of capital $=-$ and a capital which could be exploited internationally now for a non-anglophone audience in the Opera house. 
In the production for Paris's Opéra-Comique in 1850, the central role of the dramatist himself was assigned to the company's leading tenor, though for the later 1886 revision of the opera by Thomas, this role would be recast as a baritone to meet the changing configuration of the company. The intrigue unfolds once again in a highly imaginative version of Elizabethan England where the queen incognita (soprano) and her maid Olivia seek shelter from a storm on the streets of London after having been to see a play of Shakespeare's: “Quels délicieux moments nous avons passés, n'est-ce pas, Olivia ?" (Rosier/De Leuven 9 (I.iv.1.4)).33 Their refuge is a tavern where they are initially accosted by Falstaff (bass), but this action gives way to the arrival of the bard himself on the scene being hailed by the operatic chorus in the following manner:

Choeur Chantons sa gloire

Et ses brillants succès!

Que sa mémoire,

Amis, vive à jamais ! (Rosier/de Leuven 18 (I.vili.6) $)^{34}$

In direct comparison with Duval's Shakespeare Amoureux, Le Songe d'une nuit d'été characterises Shakespeare as a rising and successful dramatist and as a man wholly defined by his passionate nature. Given this profile, it comes as no surprise that the dramatist becomes immediately attracted to this disguised noblewoman in the tavern, a noblewoman who we know has already fallen under the spell of Shakespeare's dramatic art:

Shakespeare Pour vous, mon orgueilleuse, qui commandez chez les autres, vous resterez dans cette salle!

Élisabeth Dans cette salle? 
Shakespeare

Élisabeth

Shakespeare

Élisabeth
Près de moi !

Près de vous !

Je le veux !

(après l'avoir toisé) Eh bien ! je le veux aussi !

(Rosier/de Leuven 27 (I.ix $\underline{1.9}))^{35}$

At such moments as these, Francis Guinle remains most persuasive in his submission that, "Le livret peut paraître d'une platitude textuelle navrante, comme beaucoup de livrets d'opéra au XIXe siècle, et il ne doit rien à la poésie de Shakespeare, mais il faut faire la part des choses: ce qui compte ici, c'est la mise en musique" (Guinle 164). ${ }^{6}$ Given the limits of time and space, this discussion cannot extend beyond the libretto to an examination of musical interpretations of Shakespearean lives. Nonetheless, it becomes swiftly apparent that Le Songe d'une nuit d'été evokes, in keeping with expectations of nineteenth-century opera, a highly charged emotional environment focusing upon the thwarted erotic careers of the protagonists. The opera counterpoints the intense attraction between sovereign and dramatist with others being played out in the assembled company. However, as far as the protagonists are concerned, we find them at the close of the opera resigned to pursuing separately their respective paths to glory:

Élisabeth (à Shakespeare) Non, vous n'avez pas rêvé, si vous vous êtes dit: La brillante couronne qu'avaient si noblement portée Dante et le Tasse, moi, William Shakespeare, je l'avais laissée tomber, et la main d'une femme s'est baissée pour la remettre sur mon front !

(Rosier/de Leuven $73(\text { (H.xii3.12) })^{37}$ 
Once again, rather than as revenant, we encounter Shakespeare-as-lover on the nineteenth-century stage. The intrigue of Le Songe d'une nuit d'été involves grandiloquent gesturing and impassioned exchanges as is common throughout the course of the century on the operatic stage, but this production underlines the abiding need in the period to place the dramatist in romanticised and all-too-frequently domesticated settings for him to earn fullest identification on the part of the audience. As in the case of Duval's Shakespeare Amoureux, in this opera Shakespeare is introduced as the main protagonist into a linear and dominantly romantic narrative with little or no persuasive reference to the conditions of the Elizabethan theatre or society. However, the final example of Shakespeare in this discussion dramatised for the French stage goes some way to challenge these expectations.

As was witnessed at the opening of this discussion, in Le roi attend George Sand felt no need to have the bard from Stratford dominate theatrical proceedings. In that entertainment he was left to rub shoulders with the likes of Aeschylus and Beaumarchais, for example, and enjoyed no particular privileges amongst the throng of other spectral presences populating the vision with which Molière is visited. In 1868, F. Couturier's Le Comte d'Essex, Drame Historique en Cinq Actes was presented for Parisian audiences. This production is remarkable for a number of reasons - reasons which point to its neglect thus far in Shakespeare scholarship..$^{8}$ Like a great number of narratives composed for the stage such as Sand's, Couturier's Le Comte D'Essex only attributes a minor role to the English dramatist. Unsurprisingly given its title, the dominant intrigue of Couturier's play (a narrative with the most sustained interest in English history of all those discussed here) focuses upon the amorous entanglements of the Earl of Essex and his relations with his sovereign. In direct contrast with all the other dramatists in this 
study, Couturier performed at least some degree of preliminary research into his subject, integrating some details of early modern play-making, historical figures, the doomed Irish campaign and court factionalism: Raleigh (seul) - "En être réduit à faire le troubadour aux pieds d'une vieille coquette! Moi, qui ne rêve que conquête et découverte !" (Couturier 9 (I.vi2.6)).39 However, Couturier's drama is by no means a thorough-going historicised account of Elizabethan politics at the turn of the sixteenth century at the court of an ageing queen. As remains in evidence in other playtexts discussed, here the gravitational pull in Couturier's text is towards romantic heroism and intrigues of thwarted desire played out in a highly charged environment of grand gestures and impassioned declarations:

Élisabeth Appelle-moi, Elisabeth, comme autrefois... J’ai déposé ma couronne en entrant chez mon Robert !...

Essex $\quad$ Eh quoi ?... cet opiniâtre ressentiment...

Élisabeth Est éteint. Je reconnais que j'ai été injuste et cruelle envers toi.

Que veux-tu !... La jalousie m’aveuglait alors. [...]

(Couturier $6($ I.xii1.12) $))^{40}$

Unfolding in the years somewhere between 1599 and 1601, Couturier's drama evokes in very general, elsewhere highly imaginative terms the disgrace of Essex in the aftermath of the Irish campaign and his designs to organise a revolt: "Apprends qu'une conspiration dont je suis l'âme est organisée, dans le but de forcer Élisabeth d'abdiquer en faveur de Jacques d'Ecosse" (Couturier 3 (I.viı.6))..$^{41}$ In order to maintain the intense affective interest of nineteenth-century romantic dramatic narrative, Élisabeth still 
believes herself to have the potential of romantic interest for the hero, but, unfortunately, the latter has succumbed to the charms of Cathérine Sidney:

Essex La grande Elisabeth est ridicule à cette heure. Ses actes ne le prouvent-ils pas? A quarante-cinq ans d'ordinaire, à l'âge où son sexe en a fini avec les frivolités et les passions, cette vierge de l'occident, comme elle se fait audacieusement appeler, songe à s'émanciper, elle veut plaire, être aimée pour elle-même... platoniquement, il est vrai, mais sans partage; elle exige de ses favoris une chasteté, une fidélité absolue, en échange de sa faveur !... n'est-ce pas de la démence ! (Couturier 3 (I.vị1.6) $)^{42}$

Contemporary studies into early modern correspondence have indicated the frustrations of court favourites to perform the role of suitor to an ageing queen (see Hiscock 2013). If Couturier would not have had access to such documentation, he was nonetheless at pains to communicate the unruly passions and ambitions unfolding at the heart of Elizabeth's elite society. Into this volatile mêlée, Shakespeare (or Shakspeare) is introduced and accorded a cameo role. He is rendered in this instance as theatre impressario commissioned with his company (which includes a troupe of Italian dancers) to perform Hamlet for the elite society at Essex's House. Thus, framed in a narrative devoted wholly to the passionate vicissitudes of the court favourite Essex, Shakespeare finds himself consigned to fleeting appearances, such as that in which he is required to negotiate with the troupe of dancers: Shakspeare, s'avançant --_-"Trop de danse, trop de danse, maître Saltarelli, notre temps est compté, votre ballet ne doit pas durer plus de dix minutes" (Couturier 14 (世.i3.1)).43 Strikingly, Couturier's generically hybrid drama does not lose sight of the fact that all early modern performers inhabit a 
marginal status and remain in great need of patronage (and sustenance) in this fragile society-:

Tarleton (bégayant) [...] Je viens comme ambassadeur extraordinaire de Shakspeare, notre directeur, chercher une couple de jambons et un panier de vin de France pour leur rafraîchir la mémoire. (Couturier 2 (I.iil.2) $){ }^{44}$

Fortunately, in the Earl (hailed by Southampton as "le nouvel Achille" (Couturier 2 $\left.(\text { I. }+1.5)^{45}\right),-46$ the company of actors is paired with a benevolent patron who seems determined to grant their every desire: "Donnez à William Shakspeare et à ses camarades, tout, ce qu'ils vous demanderont, maître Thompson, et vous aussi maître Thomas" (Couturier 2 (Liv1.4)).47 The dramatist is thus attributed with a charmed, if transient existence in Couturier's narrative. Nonetheless, he is afforded the opportunity to impress his sovereign: "La tête est fière, l'œil illuminé, l'allure libre mais non commune, si l'esprit correspond à l'enveloppe" (Couturier 2 (I.iv1.4)). ${ }^{8}$ Indeed, Couturier's virgin queen is even given to querying the acting practices of the playhouse:

Élisabeth Pourquoi ne prenez-vous pas des femmes?

Shakspeare Je suis heureux de me trouver en communion d'idée avec ma souveraine : je m'occupe en ce moment de cette importante innovation. (Couturier $12($ (I.xiiz.12) $) 49$

As we have seen, in Duval's earlier drama Shakespeare seems to have wholly attended to this "innovation" of female players for the stage and, indeed, fallen in love with the leading actress into the bargain. Moreover, in line with Shakespeare Amoureux, Le roi 
attend and Le Songe d'une nuit d'été, Le Comte d'Essex works strenuously to respond to nineteenth-century audience expectations for extravagant tales involving high-flown passions in the romances proffered in the theatres and musical theatres of the time. Although Couturier's audience is never treated to the spectacle of a play-within-theplay as enacted by Shakespeare's company, the bard does appear with a poetic greeting in the guise of Jupiter by way of prelude to the evening's festivities at the earl's residence. Subsequently, as knowledge of his conspiracy becomes known, Essex takes flight and initially eludes Élisabeth's forces, compelling the exasperated queen to declare in metatheatric fashion: "Les lâches! Il est donc bien terrible, cet homme qu'on ne peut arriver à le saisir ? Morbleu ! (Frappant sur la table.) Je ne suis donc qu'une reine de théâtre, et je n'ai donc que des semblants de sujets que je ne puis arriver à me rendre maître d'un rebelle!" (Couturier $12(H . x+\ddot{2} 2.12)) .5^{\circ}$ Shakespeare, however, has one more function to fulfil in Le Comte d'Essex =- that of loyal retainer. Overwhelmed at the downfall of his munificent patron, the disguised Shakespeare manages to gain admission to the Earl's trial. He witnesses the sentencing of his erstwhile benefactor and tenders a final tribute: "Va mourir, héros malheureux! devant la postérité, je témoignerai du moins de ton courage!" (Couturier 19 (IV.viii4.4)). ${ }^{11}$ Having thus contributed in a minor way to the heroic mood being conjured up in the final phase of the drama, the early modern dramatist is then allowed to lapse wholly from Couturier's narrative. He has performed his function in giving what Hugo termed "local colour" (or more aptly in this context, pathos) to this evocation of late Tudor culture, symbolising both the artistic achievement and the divided allegiances which lay at the heart of this theatrical evocation of the Elizabeth's court. 


\section{Concluding Thoughtssion}

This discussion is by no means exhaustive in its consideration of the dramatizations of Shakespeare-the-man on the nineteenth-century stage. However, in analysing the many and various productions by Duval, Somerset, Moncrieff, Sand, Coyne, Thomas/Rosier/de Leuven and Couturier, we encounter again and again a variously revered, exceptionally talented, loyal and passionate figure whose qualities bear ample comparison with a sequence of heroic protagonists in evidence throughout the century. Such qualities became common currency for romantic fictions produced on both stage and page, and evocations of Shakespeare were, as we have seen, frequently made to conform to this taste culture. However, it remains remarkable that we are never in such intrigues introduced into Jacobean London. The figure of James VI/I must, it seems, be occluded or wholly excluded from such narratives, most frequently so that the dramatised playwright can focus his attentions (and affections) on an admiring Elizabeth. In addition, at no point in any of the texts is there any evidence of a thoroughgoing interest in the conditions of late Tudor conditions of play-making and or the practices of court society in that apparently distant age.

This discussion draws to close with Couturier's Le Comte d'Essex, a text which has been neglected by Shakespearean scholarship. This state of affairs begs-raises further questions about the accounts which proliferate of the bard in the decades and centuries after his death and which criticism has sought thus far to re-tell. In the desire to account for the production, circulation and consumption of Shakespearean texts and lives, there has often been an imperative to search for the bard as inevitably the dominant presence in a narrative. While so many nineteenth-century dramas have been scrutinised by Shakespeare scholarship, Couturier's drama has perhaps been overlooked because it 
attributes only a very minor status to a dramatist when critical appetites are frequently concerned to highlight his growing, and pervasive presence in the cultural life of nations. A similar case might be made for the relative neglect of eighteenth-century evocations of spectral Shakespeares so often discovered in the midst of a host of other, mostly equally venerated luminaries or relegated to a prologue or epilogue.

This discussion of some of the nineteenth-century stage evocations of Shakespeare highlights some of the contrary motions clearly at work in the reception of his works and life as the century unfolded on both sides of the English Channel, uncovering some of the harmonies and disharmonies of representation. In order to appreciate more fully the accounts of the phenomena of local and global Shakespeares in later ages, it may be that critical narratives need to strain a little harder to account for those occasions when the dramatist appears amongst equals and/or when the presence of the bard is displaced, marginalised, attenuated or almost eclipsed, emerging intermittently from the wings in the many and various narratives composed for the stage and the reading public. As was seen when Betterton was called forth as the spirit of Shakespeare in the prologue for Dryden's Troilus and Cressida in 1679, in order to take a more comprehensive account of Shakespeare's reception history, there still remains a need to identify Shakspeare s'avancant even when he must give place to others.

\section{WORKS CITED}

Anon. Memoirs of the Shakespear's-Head in Covent-Garden: In which many entertaining Adventures, and several remarkable Characters. By the Ghost of Shakespear. In Two Volumes. London: F. Noble, 1755. Print. 
Arnold, Matthew. Dover Beach and Other Poems. New York: Dover Thrift, 1994. Print.

Boyd, Elizabeth. Don Sancho: or the Students whim, a ballad opera of two acts, with Minerva's triumph, a masque. London: G. Parker, 1739. Print.

Brontë, Charlotte. The Letters of Charlotte Brontë, ed. Margaret Smith, vol. I 1829-1847.

Oxford: Clarendon, 1995. Print.

Brown, Charles Armitage. Shakespeare's Autobiographical Poems, being his Sonnets elearly developed: with his Character drawn chiefly from his Works. London:James Bohn, 1838. Print.

Carlyle, Thomas. On Heroes, Hero-Worship and the Heroic in History. London: Chapman and Hall, 1840. Print.

Connolly, Annaliese and Lisa Hopkins eds. Essex. The Cultural Impact of an Elizabethan Gourtier. Manchester: Manchester University Press, 2013. Print.

Couturier, F. Le Comte d'Essex, Drame Historique en Cinq Actes. Paris: E. Dentu, 1868.

Coyne, J. Stirling. This House is to Sold; (The Property of the Late William Shakespeare) Inquire Within. A Musical Extravaganza in One Act. London: Nat. Acting Drama Office/Nassau Steam Press, s.d.).Print.

Curling, Henry. Shakspere; The Poet, the Lover, the Actor, the Man. A Romance. London: Richard Bentley, 1848). Print.

Davenant, Sir William. Macbeth a tragaedy: with all the alterations, amendments, additions, and new songs: as it's now acted at the Dukes Theatre. London, 1674. Print.

Dobson, Michael. The Making of the National Poet. Shakespeare, Adaptation and Authorship, 1660-1769. Oxford: Clarendon Press, 1992. Print. 
Dobson, Michael and Nicola J. Watson. England's Elizabeth. An Afterlife in Fame and Fantasy. Oxford: Oxford University Press, 2002. Print.

Drake, Nathan. Noontide Leisure; or, Sketches in Summer, outlines from Nature and Imagination, and including A Tale of the Days of Shakspere... in 2 vols. London: T. Cadell, 1824 . Print.

Dryden, John. All for love, or, The world well lost, a tragedy [...] written in imitation of Shakespeare's stile. London, 1678. Print.

Dryden, John. Troilus and Cressida, or, Truth found too late a tragedy, as it is acted at the Dukes Theatre: to which is prefix'd, a preface containing the grounds of eriticism in tragedy. London, 1679. Print.

Duval, Alexandre. Shakespeare Amoureux, ou La Pièce à l'Étude, Comédie en un Acte et en Prose. Paris: Vente Librairie, 1830 . Print.

Ewbank, Inga-Stina. "As They Liked It: Shakespearean Comedy goes Continental”, pp. 128-145, in Marshall and Poole 2003. Print.

Fielding, Henry. Contributions to "The Champion" and Related Writings, ed. W. B. Coley. Oxford: Clarendon Press, 2003. Print.

Franssen, Paul. Shakespeare's Literary Lives: The Author as Character in Fiction and Film. Cambridge: Cambridge University Press, 2016. Print.

Granville, George (Lord Lansdowne). The Jew of Venice. A Comedy. London: Ber. Lintott, Fleet Street, 1701. Print.

Gross, John ed. After Shakespeare. An Anthology. Oxford: Oxford University Press, 2002. Print. 
Guinle, Francis. The Concord of this Discord: La Structure musicale du "Songe d'une nuit d'été" de William Shakespeare. Saint Etienne: Publications de l'Université de Saint-Etienne, 2003. Print.

Hackett, Helen. Shakespeare and Elizabeth. The Meeting of Two Myths. Princeton: Princeton University Press, 2009. Print.

Halsall, Albert W. Victor Hugo and the Romantic Drama. Toronto: University of Toronto Press, 1998. Print.

Henderson, Diana E. "Othello Redux?: Scott's Kenilworth and the Trickiness of 'Race' on the Nineteenth-century Stage", pp. 14-29, in Marshall and Poole 2003. Print. Hiscock, Andrew. "Achilles alter: the heroic lives and afterlives of Robert Devereux, and Earl of Essex", pp. 101-32, in Connolly and Hopkins 2013. Print.

Hiscock, Andrew. “' $O$, Tom Thumb! Tom Thumb! Wherefore art thou Tom Thumb?’: Early Modern Drama and the Eighteenth-century Writer - Henry Fielding and Fanny Burney". The Ben Jonson Journal 21.2 (2014), 228-63. Print.

Hiscock, Andrew and Lina Perkins Wilder eds. The Routledge Handbook of Shakespeare and Memory. London: Routledge, 2017. Print.

Hoenselazrs, Ton, and Clara Calvo. "Shakespeare Eurostar: Calais, the Continent, and the Operatic Fortunes of Ambroise Thomas", pp. 147-64, in Maley and TudeauClayton 2010. Print.

Holland, Peter. "Dramatizing the Dramatist". In Peter Holland ed. Shakespeare Survey 58 "Writing About Shakespeare". Cambridge: Cambridge University Press, 2005, pp. 137-47. Print.

Hugo, Victor. Cromwell, ed. Annie Uberfeld. Paris : GF-Flammarion, 1968. Print. 
Knight, Charles. William Shakspere. A Biography. London: W. Clawes \& Sons, 1843. Print.

Manningham, John. The Diary of John Manningham of the Middle Temple 1602-1603, newly edited in complete and unexpurgated form from the original manuscript in the British Museum, ed. and intro. by Robert Parker Sorlien. Hanover NH: University of Rhode Island/University Press of New England, 1976. Print. Maley, Willy and Margaret Tudeau-Clayton eds. This England, That Shakespeare. New Angles on Englishness and the Bard. Farnham: Ashgate, 2010. Print.

Marshall, Gail ed. Shakespeare in the Nineteenth Century. Cambridge: Cambridge University Press, 2012. Print.

Marshall, Gail and Adrian Poole eds. Victorian Shakespeare, Volume 1. Theatre, Drama and Performance. Houndmills: Palgrave Macmillan, 2003. Print.

Moncrieff, W. T. Shakspeare's Festival; or, New Comedy of Errors! A Drama, in Two Acts. London: Thomas Richardson, 1831. Print.

Murphy, Paul Thomas. Toward a Working-Class Canon. Literary Criticism in British Working-Class Periodicals, 1816-58. Columbus OH: Ohio State University Press, 1994. Print.

Newey, Katherine. "Shakespeare and the Wars of the Playbills", pp.13-28, in Marshall and Poole 2003. Print.

Nichols, James W. "Shakespeare as a Character in Drama: 1679-1899". Educational Theatre Journal 15, 1 (March 1963), 24-32. Print.

Poole, Adrian. Shakespeare and the Victorians. London: Bloomsbury, 2014. Print. Prince, Kathryn. "Shakespeare in the Periodicals", pp. 60-75, in Marshall 2012. Print. Robert, Clémence. William Shakspère. Paris: Gabriel Rous et Cassanet, 1844. Print. 
Rosier, Josèphe, and Adolphe de Leuven. Le Songe D'une Nuit d'Eté. Music by Ambroise Thomas In La Bibliothèque Dramatique. Choix des Pièces Nouvelles Jouées sur Tous les Théâtres de Paris, vol. XXVII. Paris: Michel Lévy Frères, 1849. Print.

Sand, George. Deuvres Complètes. Théâtre I: Cosima, Le roi attend, François le Champi, Claudie, Molière. Paris: Calmann Lévy, 1877 . Print.

Sanders, Julie. Shakespeare and Music. Afterlives and Borrowings. London: Polity Press, zo07. Print.

Schoch, Richard W. Not Shakespeare. Bardolatry and Burlesque in the Nineteenth Century. Cambridge: Cambridge University Press, 200z. Print.

Schmidgall, Gary, Shakespeare and Opera. New York: Oxford University Press, 1990.

Print.

Scott, Sir Walter. Kenilworth, intro. W. M. Parker. London/New York: J. M. Dent/E.P. Dutton, 1959. Print. Scott, Sir Walter. The Journal of Sir Walter Scott, ed. W. E. K. Anderson. Oxford: Clarendon Press, 1972. Print.

Schoenbaum, Samuel. Shakespeare's Lives. Oxford: Clarendon Press, 1991. Print.

Scot, Sir Walter. The Journal of Sir Walter Stat, ed. W. E. K. Anderson. Oxford: Clarendon Press, 1972 . Print.

Shelley, Percy Bysshe. Shelley's Prose, or The Trumpet of a Prophecy, ed. David Lee Clark. Albuquerque: University of New Mexico Press, 1954. Print.

Sillars, Stuart. Shakespeare and the Victorians. Oxford: Oxford University Press, 2013. Print.

Somerset, Charles A. Shakspeare's Early Days. A Drama, in Two Acts. Dicks' British Drama 792, s.d. Print. 
Taylor, David Francis. "Shakespeare and drama", pp. 129-47, in Marshall 2012.

Trollope, Anthony. The Letters of Anthony Trollope, ed. Bradford Allen Booth. Westport, Conn.: Greenwood Press, 1951 . Print.

Wells, Stanley ed. Nineteenth-Century Shakespeare Burlesques, vol. IV. London, Diploma Press, 1978. Print.

Wells, Stanley. Shakespeare For All Time. Oxford: Oxford University Press, 2003. Print.

West, Shearer. "Shakespeare, Memory and the Visual Arts", pp. 46-61, in Hiscock and Wilder 2017. Print.

Williams, Robert Folkestone. The Youth of Shakspeare. Paris: Baudry's European Library, 1839. Print.

Worrall, David. The Politics of Romantic Theatricality, 1787-1832. The Road to the Stage. London: Palgrave MacMillan, 2007. Print.

\section{NOTESNotes}

${ }_{1}^{1}$ This research was completed under the auspices of a Marie Sklodowska-Curie Research Fellowship (2016-18) at the Institut de Recherche sur la Renaissance, l'Age Classique et les Lumières, Université Paul-Valéry, Montpellier III.

${ }^{2}$ For further discussion here, see Dobson 74-5.

${ }_{4}^{3}$ For further discussion, see: Franssen 24ff; Poole $10 \mathrm{ff}$.

${ }_{4}^{4}$ Inga-Stina Ewbank has also interestingly drawn attention to Sand's adaptation of As You

Like It for the French theatre (Ewbank 140).

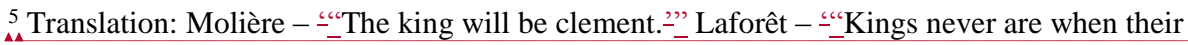
entertainments are concerned.:-"'=- Unless otherwise indicated, all translations from French are my own. 
${ }^{6}$ Translation: “'I am a man in despair, a lost man, a condemned man! Ah! cursed be that time when I accepted the orders of a king!"'”

${ }_{4}^{7}$ Translation: -"What is a king ? A man who has the power to do good, and it is only when he does this that he rises above the level of other men.'-

${ }_{\triangle}^{8}$ Translation: ‘_a cloud slowly envelops him ; a chorus sings from behind the cloud. When the cloud evaporates, around the sleeping Molière can be seen standing the spirits of ancient and modern writers: Plautus, Terence, Aeschylus, Sophocles, Euripides, Shakespeare,

Voltaire, Rousseau, Sedaine, Beaumarchais etc. The Muse of the theatre is in the midst of them, very close to Molière?."."

${ }^{9}$ Translation: “" A host of strange events is unfolding in this new age. The whole mass of the earth has been shaken like a rickety mechanism, and tempests have come into being $[\ldots]$

With regard to myself, I was never one of those who tolerated injustice with an easy expression and, if on occasions I was given to laughter like Molière, my spirit and my countenance remained serious.'-"

${ }_{10}^{10}$ Translation: “"I do indeed see a king, but that king is no longer called Louis XIV; he is called the people! The sovereign people!'”,

11 This convention of Shakespearean representation continued throughout the century as may be evidenced in the _-_Procession of Characters from Shakespeare's Plays-"” (1840, attr.

Daniel Maclise) and Sir John Gilbert's “_The Plays of Shakespeare’”- (1849), for example.

12 For more general discussion of the contribution of these artists to the cultural debate surrounding Shakespeare in this period, see West 52-3.

${ }_{13}^{13}$ For an account of Scott's sources for his novel, see Hackett 55. For earlier textual accounts in Rowe's edition of Shakespeare's deer-poaching reputation, see Schoenbaum 68

${ }_{14}^{14}$ For further discussion here, see Henderson 16.
Formatted: Font: Times New Roman

Formatted: Font: Times New Roman

Formatted: Font: Times New Roman

Formatted: Font: Times New Roman

Formatted: Font: Times New Roman

Formatted: Font: Times New Roman

Formatted: Font: Times New Roman

Formatted: Font: Times New Roman

Formatted: Font: Times New Roman

Formatted: Font: Times New Roman

Formatted: Font: Times New Roman

Formatted: Font: Times New Roman

Formatted: Font: Times New Roman Formatted: Font: Times New Roman

Formatted: Font: Times New Roman

Formatted: Font: Times New Roman

Formatted: Font: Times New Roman

Formatted: Font: Times New Roman 
${ }_{15}$ A few examples of this genre do exist also in the eighteenth century. Interestingly importing once again the ghost of Shakespeare into the fiction, see, for example, Memoirs of the Shakespear's-Head in Covent-Garden: In which many entertaining Adventures, and several remarkable Characters. By the Ghost of Shakespear. In Two Volumes (1755). Here, the narrator, having ““_supp'd merrily, with a few select Friends, in the Tavern, known by the Name of the Shakespear's Head"', finds his slumbers are brought to a close with the approach of ‘_a Figure in every Part resembling that we see drawn for Shakespear: There ran a sacred Tremor thro' my Limbs-”.'. (Anon, Memoirs $1 \underline{1}$ : 2, 4).

${ }_{16}^{16}$ For further discussion of the French dramatizations of Scott's novel, see Halsall 48.

${ }_{17}^{17}$ For discussion of the ways in which Curling's work found its way later on stage and screen, see: Hackett 82 .

18 Translation: «"it seems to me that their closeness does me good, that the life of my spirit enters my head. I dream in verse, I have delicious visions"”; ;“_During my waking hours, my dreaming continues.,-

${ }_{19}$ Translation: “" "this god of the theatre-"”.

${ }^{20}$ Charles Knight's William Shakspere. A Biography (1843) also mined the same vein as

Carlyle’s discussion, unveiling «“‘a man who stands above all other individual men, above all ranks of men; in comparison with whom, in his permanent influence upon mankind, generations of nobles, fighting men, statesmen, princes, are but as dust?2”' (Knight 19). ${ }_{21}^{21}$ Franssen underlines: ‘“"The name Clarence may have been derived from a glance at the dramatis personae in Shakespeare's Richard III, one of the three Shakespearean tragedies referred to in Duval's play - though the excerpt supposedly taken from this play and spoken by Clarence in rehearsal seems to be Duval's own invention. In the dialogue about Othello, which Shakespeare is currently writing, Desdemona's name is given as “"'Hedelmone"-, as in Ducis's neclassical adaptation, and she is called Othello's "“-maîtresse"”-' rather than his wife.
Formatted: Font: Times New Roman Formatted: Font: Times New Roman

Formatted: Font: Times New Roman
Formatted: Font: Times New Roman
Formatted: Font: Times New Roman
Formatted: Font: Times New Roman
Formatted: Font: Times New Roman
Formatted: Font: Times New Roman
Formatted: Font: Times New Roman
Formatted: Font: Times New Roman
Formatted: Font: Times New Roman


Clearly, Duval's knowledge of Shakespeare's life and works is limited and

derivative'derivative.." See Franssen 38.

${ }^{22}$ Translation: “-"What demon drives me back to this house? [...] O Shakespeare! you paint the passions and the weaknesses of mankind, but you cannot preserve yourself from them!2"' ${ }^{23}$ Translation: “"She believes the truth to be a fiction'.."

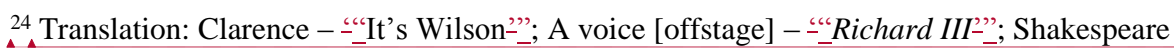
(advancing in a spirited manner to the casement) “" Richard III has come too late. William the

Conqueror has already taken the fortress..- This comic offering approximates remarkably closely the 1601 anecdote to be found in the diary of John Manningham: “-_Upon a tyme when Burbridge played Rich[ard] 3. there was a Citizen grewe soe farr in liking with him, that before shee went from the play shee appointed him to come that night unto hir by the name of Ri[chard] the 3. Shakespeare, overhearing their conclusion, went before, was intertained, and at his game ere Burbidge came. Then message being brought that Richard the $3^{\mathrm{d}}$. was at the dore, Shakespeare caused returne to be made that William the Conquerour was before Rich[ard] the 3. Shakespeare's name William?-' (Manningham 75). Robert Parker Sorlien underlines that Manningham's diary first came to attention in modern critical debate in 1831 (Manningham 1. See also Schoenbaum 17, 247). Given the absence of historical sensitivity in Duval's play as a whole, it is not credible that he had some premature access to the diary and thus it would seem that this coup de théâtre relies on some felicitous punning with the title of “-“Guillaume le Conquérant””-.

${ }^{25}$ In this context, see Kathryn Prince's contention: “Formatted: Font: Times New Roman century's pre-eminent publishing genre, contributed to Shakespeare's popularization by reviewing new publications and productions, and also by writing about the man and his works in a manner calculated to engage different intended readerships, including those for whom these articles constituted a first introduction to Shakespeare."' See-(Prince 60). Formatted: Font: Times New Roman Formatted: Font: Times New Roman Formatted: Font: Times New Roman

Formatted: Font: Times New Roman

Formatted: Font: Times New Roman

Formatted: Font: Times New Roman 
${ }^{26}$ For analyses of how the 1843 Theatre Regulation Act repealed the clatses of the 1737 Licensing Act which

had limited the performance of spoken drama to the theatres of Drury Lane and Covent Garden, see, for

example: Newey 16-7; Sillars 50-5.

${ }^{27}$ For analyses of how the 1843 Theatre Regulation Act repealed the clauses of the 1737

Licensing Act which had limited the performance of spoken drama to the theatres of Drury

$\underline{\text { Lane and Covent Garden, see, for example: Newey 16-7; Sillars 50-5. }}$

${ }_{\perp}^{28}$ For further discussion here, see Hackett 90: ‘_burlesque may be seen as recuperating and reinforcing Shakespeare's cultural supremacy. Yet at the same time it made Shakespeare's cultural meaning an object of contestation. [...] Burlesque assumed assumed extensive knowledge of Shakespeare's works in its audiences and thereby laid claim to him for popular culture. As we have seen, Elizabeth's cultural meanings had always been multiple and conflicting; now Shakespeare's cultural meanings seemed to be fissuring and proliferating too.'?"

${ }^{29}$ For further discussion here, see Hackett 71.

${ }^{30}$ For further discussion here, see Newey 23-4.

${ }_{11}^{31}$ For further discussion here, see: Schmidgall, 331; Sillars 85.

${ }_{22}^{32}$ Stanley Wells also justly stresses Shakespeare as a major source of musical inspiration for Berlioz and Mendelssohn.See Wells (Shakespeare For All Time 285-6). Hackett also illuminatingly draws attention to Arthur Sullivan's 1865 composition Kenilworth: A Masque in the Days of Queen Elizabeth (Hackett 60).

33 Translation: “_What delightful moments we have spent this evening, haven’t we, Olivia?-” ${ }^{34}$ Translation: Chorus - «“_Let us sing his glory__And his brilliant successes! Friends, let his memory live forever!"'”

${ }_{35}^{35}$ Translation: Shakespeare - “_.AAs for you, my proud one, who gives her orders elsewhere,

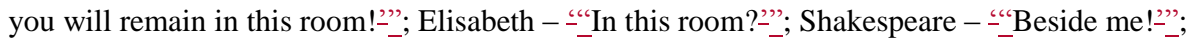

Formatted: Font: Times New Roman

Formatted: Font: Times New Roman

Formatted: Font: Times New Roman

Formatted: Font: Times New Roman

Formatted: Font: Times New Roman

Formatted: Font: Times New Roman

Formatted: Font: Times New Roman

Formatted: Font: Times New Roman

Formatted: Font: Times New Roman

Formatted: Font: Times New Roman

Formatted: Font: Times New Roman

Formatted: Font: Times New Roman

Formatted: Font: Times New Roman

Formatted: Font: Times New Roman

Formatted: Font: Times New Roman

Formatted: Font: Times New Roman

Formatted: Font: Times New Roman

Formatted: Font: Times New Roman

Formatted: Font: Times New Roman

Formatted: Font: Times New Roman 


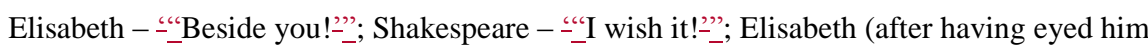
scornfully) "Well! I wish it also!",

${ }_{4}^{36}$ Translation: “"'The libretto can seem to be a text of overwhelming vacuousness, like many opera libretti in the nineteenth century, and it owes nothing to the poetry of Shakespeare, but Formatted: Font: Times New Roman Formatted: Font: Times New Roman the context must be taken into consideration: what counts here is the musical setting."'” ${ }^{37}$ Translation: Elisabeth (to Shakespeare) - ¿“-_-No, you have not dreamed, if you say to yourself: the sparkling coronet which Dante and Tasso wore with such nobility, I, William

Shakespeare let it fall and the hand of a woman bent down and restored it to my brow!"'-

${ }^{38}$ In adopting this Elizabeth-Essex narrative for theatrical entertainment, Couturier may have been influenced by seventeenth-century French dramas, such as La Calprénède's Le Comte d'Essex (1637-8), or later French prose fictions treating this intrigue. However, these dramas and prose narratives do not afford Shakespeare even the cameo role that he manages to secure in Couturier's play. For further discussion here, see Dobson \&and Watson 89.

${ }^{39}$ Translation: Raleigh (alone) - s“' To be reduced to playing a wooing minstrel at the feet of an old coquette! I, who dream only of conquest and discovery!'-”

${ }_{40}^{40}$ Translation: Elisabeth - ‘“Call me, Elisabeth, as you used to... I left my crown at the door in entering the residence of my Robert !....””; Essex - ﹎._So? ...this unrelenting resentment...."”; Elisabeth - - “'Is extinguished. I understood that I had been unjust and cruel towards you. What else do you expect!... Jealousy was blinding me then..-

${ }_{4}^{41}$ Translation: ‘-'Learn then that a conspiracy has been organised and I am at its head, a conspiracy which aims to compel Elisabeth to abdicate in favour of James of Scotland -.." ${ }_{42}^{42}$ Translation: ‘“"The great Elisabeth has now become ridiculous. Don’t her actions indicate this. At forty-five years old, at an age when her sex has finished with trifles and amorous attachments, this virgin of the western world, as she has daringly called herself, dreams of liberty, she wishes to be liked, to be loved for herself..... platonically, it must be admitted,

Formatted: Font: Times New Roman Formatted: Font: Times New Roman

Formatted: Font: Times New Roman

Formatted: Font: Times New Roman

Formatted: Font: Times New Roman Formatted: Font: Times New Roman

Formatted: Font: Times New Roman

Formatted: Font: Times New Roman 
but unreservedly; she demands of her favourites that they be chaste, faithful, devoted, in exchange for her favour! ...isn't this madness!?.."

${ }_{4}^{43}$ Translation: Shakespeare, advancing - ¿“"Too much dancing, too much dancing, master

Saltarelli, our time is limited, your ballet must not last more than ten minutes?.."

44 Translation: Tarleton (stammering) ‘“'I come as ambassador extraordinary from

Shakespeare, our director, in order to look for a pair of hams and a flagon of wine to refresh the company's powers of memory?.."

45.Translation: 'the new Achilles'. For further discussion here, see Hiscock 2013.

${ }^{46}$ Translation: "the new Achilles." For further discussion here, see Hiscock 2013.

${ }_{4}^{47}$ Translation: :“Give to Shakespeare and his fellow players everything they request, master

Thompson, and you also, master Thomas..-

48 Translation: ‘-_He has a proud countenance, a fiery eye, a bearing frank but above the common, and if his mind fits his outward appearance $=.$.

${ }^{49}$ Translation: Elisabeth - ¿“'Why don’t you accept women into the company?_-'-;

Shakespeare - ¿'II am pleased to discover that my sovereign's thoughts mirror my own: at this very moment I am overseeing this important innovation

${ }^{50}$ Translation: “`The cowards! See how dreadful it is that this man eludes capture by everyone! Zounds ! (striking the table) So I am nothing more that a queen performing on the stage, and I have only the shadows of subjects for I have no way of overpowering this rebel!'”,

51 Translation : ““And so go to your death, wretched hero! I at least will give proof of your courage to posterity!"’"

\begin{tabular}{l} 
Formatted: Font: Times New Roman \\
Formatted: Font: Times New Roman \\
Formatted: Font: Times New Roman \\
Formatted: Font: Times New Roman \\
Formatted: Font: Times New Roman \\
Formatted: Font: Times New Roman \\
Formatted: Font: Times New Roman \\
Formatted: Font: Times New Roman \\
Formatted: Font: Times New Roman \\
Formatted: Font: Times New Roman \\
\hline
\end{tabular}

\section{$\underline{\text { References }}$}

Formatted: Font: Times New Roman

Formatted: Font: Times New Roman

Formatted: Font: Times New Roman

Formatted: Font: Times New Roman

Formatted: Font: Times New Roman 
Anon. Memoirs of the Shakespear's-Head in Covent-Garden: In which many entertaining Adventures, and several remarkable Characters. By the Ghost of Shakespear. In Two Volumes. London: F. Noble, 1755. Print.

Arnold, Matthew. Dover Beach and Other Poems. New York: Dover Thrift, 1994. Print.

Boyd, Elizabeth. Don Sancho: or the Students whim, a ballad opera of two acts, with Minerva's triumph, a masque. London: G. Parker, 1739. Print.

Brontë, Charlotte. The Letters of Charlotte Brontë. Ed. Margaret Smith. Vol. 1: 1829-1847. Oxford: Clarendon Press, 1995. Print.

Brown, Charles Armitage. Shakespeare's Autobiographical Poems, being his Sonnets clearly developed: with his Character drawn chiefly from his Works. London: James Bohn, 1838. Print.

Carlyle, Thomas. On Heroes, Hero-Worship and the Heroic in History. London: Chapman and Hall, 1840. Print.

Connolly, Annaliese and Lisa Hopkins eds. Essex: The Cultural Impact of an Elizabethan Courtier. Manchester: Manchester UP, 2013. Print.

Couturier, F. Le Comte d'Essex, Drame Historique en Cinq Actes. Paris: E. Dentu, 1868.

Coyne, J. Stirling. This House to be Sold; (The Property of the Late William Shakespeare) Inquire Within. A Musical Extravaganza in One Act. London: Nat. Acting Drama Office/Nassau Steam Press, n.d...Print.

Curling, Henry. Shakspere; The Poet, the Lover, the Actor, the Man. A Romance. London: $\underline{\text { Richard Bentley, 1848. Print. }}$

Davenant, Sir William. Macbeth a tragaedy: with all the alterations, amendments, additions, and new songs: as it's now acted at the Dukes Theatre. London, 1674. Print.

Dobson, Michael. The Making of the National Poet: Shakespeare, Adaptation and Authorship, 1660-1769. Oxford: Clarendon Press, 1992. Print. 
Dobson, Michael and Nicola J. Watson. England's Elizabeth: An Afterlife in Fame and

Fantasy. Oxford: Oxford UP, 2002. Print.

Drake, Nathan. Noontide Leisure; or, Sketches in Summer, outlines from Nature and Imagination, and including A Tale of the Days of Shakspere... in 2 vols. London: T. Cadell, 1824. Print.

Dryden, John. All for love, or, The world well lost, a tragedy [...] written in imitation of Shakespeare's stile. London, 1678. Print.

Dryden, John. Troilus and Cressida, or, Truth found too late a tragedy, as it is acted at the Dukes Theatre: to which is prefix'd, a preface containing the grounds of criticism in tragedy. London, 1679. Print.

Duval, Alexandre. Shakespeare Amoureux, ou La Pièce à l'Étude, Comédie en un Acte et en Prose. Paris: Vente Librairie, 1830. Print.

Ewbank, Inga-Stina. “As They Liked It: Shakespearean Comedy goes Continental.” In

Marshall and Poole eds: 128-145. Print.

Fielding, Henry. Contributions to "The Champion" and Related Writings, ed. W. B. Coley. Oxford: Clarendon Press, 2003. Print.

Franssen, Paul. Shakespeare's Literary Lives: The Author as Character in Fiction and Film. Cambridge: Cambridge UP, 2016. Print.

Granville, George (Lord Lansdowne). The Jew of Venice. A Comedy. London: Ber. Lintott, Fleet Street, 1701. Print.

Gross, John ed. After Shakespeare: An Anthology. Oxford: Oxford UP, 2002. Print.

Guinle, Francis. The Concord of this Discord: La Structure musicale du "Songe d'une nuit d'été" de William Shakespeare. Saint Etienne: Publications de 1'Université de SaintEtienne, 2003. Print. 
Hackett, Helen. Shakespeare and Elizabeth: The Meeting of Two Myths. Princeton: Princeton

$$
\text { UP, 2009. Print. }
$$

Halsall, Albert W. Victor Hugo and the Romantic Drama. Toronto: $\mathrm{U}_{\star}$ of Toronto P, 1998.

Print.

Henderson, Diana E. "Othello Redux? Scott's Kenilworth and the Trickiness of 'Race' on the Nineteenth-century Stage." In Marshall and Poole eds: 14-29. Print.

Hiscock, Andrew. "Achilles alter: the heroic lives and afterlives of Robert Devereux, 2nd Earl of Essex.", In Connolly and Hopkins eds: 101-32. Print.

Hiscock, Andrew. “'O, Tom Thumb! Tom Thumb! Wherefore art thou Tom Thumb?': Early Modern Drama and the Eighteenth-century Writer - Henry Fielding and Fanny Burney." The Ben Jonson Journal 21.2 (2014): 228-63. Print.

Hiscock, Andrew and Lina Perkins Wilder eds. The Routledge Handbook of Shakespeare and Memory. London: Routledge, 2017. Print.

Hoenselaars, Ton, and Clara Calvo. "Shakespeare Eurostar: Calais, the Continent, and the Operatic Fortunes of Ambroise Thomas.” In Maley and Tudeau-Clayton eds: 147-64. Print.

Holland, Peter. "Dramatizing the Dramatist." Shakespeare Survey 58: 137-47. Print.

Hugo, Victor. Cromwell. Ed. Annie Uberfeld. Paris: GF-Flammarion, 1968. Print

Knight, Charles. William Shakspere. A Biography. London: W. Clawes \& Sons, 1843. Print. Manningham, John. The Diary of John Manningham of the Middle Temple 1602-1603, newly edited in complete and unexpurgated form from the original manuscript in the British Museum. Ed. and intro. Robert Parker Sorlien. Hanover NH: U, of Rhode Island/UP of New England, 1976. Print.

Maley, Willy and Margaret Tudeau-Clayton eds. This England, That Shakespeare: New Angles on Englishness and the Bard. Farnham: Ashgate, 2010. Print.
Formatted: Font: Times New Roman

Formatted: Font: Times New Roman

Formatted: Font: Times New Roman

Formatted: Font: Times New Roman

Formatted: Font: Times New Roman

Formatted: Font: Times New Roman Formatted: Font: Times New Roman Formatted: Font: Times New Roman

Formatted: Font: (Default) Times New Roman Formatted: Font: (Default) Times New Roman Formatted: Font: (Default) Times New Roman

Formatted: Font: (Default) Times New Roman

Formatted: Font: Times New Roman

Formatted: Font: Times New Roman Formatted: Font: Times New Roman

Formatted: Font: Times New Roman Formatted: Font: Times New Roman Formatted: Font: Times New Roman Formatted: Font: Times New Roman Formatted: Font: Times New Roman Formatted: Font: Times New Roman

Formatted: Font: Times New Roman 
Marshall, Gail ed. Shakespeare in the Nineteenth Century. Cambridge: Cambridge UP, 2012. Print.

Marshall, Gail and Adrian Poole eds. Victorian Shakespeare, Volume 1: Theatre, Drama and Performance. Houndmills: Palgrave Macmillan, 2003. Print.

Moncrieff, W. T. Shakspeare's Festival; or, New Comedy of Errors! A Drama, in Two Acts. London: Thomas Richardson, 1831. Print.

Murphy, Paul Thomas. Toward a Working-Class Canon. Literary Criticism in British WorkingClass Periodicals, 1816-58. Columbus: Ohio State UP 1994 . Print.

Newey, Katherine. "Shakespeare and the Wars of the Playbills." In Marshall and Poole eds:

$$
\text { 13-28. Print. }
$$

Nichols, James W. "Shakespeare as a Character in Drama: 1679-1899”. Educational Theatre Journal 15, 1 (March 1963): 24-32. Print.

Poole, Adrian. Shakespeare and the Victorians. London: Bloomsbury, 2014. Print.

Prince, Kathryn. "Shakespeare in the Periodicals." In Marshall ed.: 60-75. Print.

Robert, Clémence. William Shakspère. Paris: Gabriel Rous et Cassanet, 1844. Print.

Rosier, Josèphe, and Adolphe de Leuven. Le Songe D'une Nuit d'Eté. Music by Ambroise Thomas In La Bibliothèque Dramatique. Choix des Pièces Nouvelles Jouées sur Tous les Théâtres de Paris, vol. XXVII. Paris : Michel Lévy Frères, 1849. Print.

Sand, George. Oeuvres Complètes. Théâtre 1: Cosima, Le roi attend, François le Champi, Claudie, Molière. Paris: Calmann Lévy, 1877. Print.

Sanders, Julie. Shakespeare and Music: Afterlives and Borrowings. London: Polity Press, 2007. Print.

Schoch, Richard W. Not Shakespeare: Bardolatry and Burlesque in the Nineteenth Century. Cambridge: Cambridge UP, 2002. Print.

Schmidgall, Gary. Shakespeare and Opera. New York: Oxford UP, 1990. Print.
Formatted: Font: Times New Roman

Formatted: Font: Times New Roman

Formatted: Font: Times New Roman

Formatted: Font: Times New Roman

Formatted: Font: Times New Roman Formatted: Font: Times New Roman

Formatted: Font: Times New Roman

Formatted: Font: Times New Roman Formatted: Font: Times New Roman

Formatted: Font: Times New Roman

Formatted: Font: Times New Roman

Formatted: Font: Times New Roman

Formatted: Font: Times New Roman

Formatted: Font: Times New Roman Formatted: Font: Times New Roman 
Scott, Sir Walter. Kenilworth, intro. W. M. Parker. London/New York: J. M. Dent/E. P. Dutton, 1959. Print.

$\underline{\text { Scott, Sir Walter. The Journal of Sir Walter Scott. Ed. W. E. K. Anderson. Oxford: Clarendon }}$ Press, 1972. Print.

$\underline{\text { Schoenbaum, Samuel. Shakespeare's Lives. Oxford: Clarendon Press, 1991. Print. }}$

Shelley, Percy Bysshe. Shelley's Prose, or The Trumpet of a Prophecy. Ed. David Lee Clark.

Albuquerque: $\mathrm{U}_{\star}$ of New Mexico $\mathrm{P}$ 1954. Print.

Sillars, Stuart. Shakespeare and the Victorians. Oxford: Oxford UP, 2013. Print.

$\underline{\text { Somerset, Charles A. Shakspeare's Early Days. A Drama, in Two Acts. Dicks' British Drama }}$ $\underline{792, \text { n.d. Print. }}$

Taylor, David Francis. "Shakespeare and Drama." In Marshall: 129-47.

Trollope, Anthony. The Letters of Anthony Trollope. Ed. Bradford Allen Booth. Westport, Conn.: Greenwood Press, 1951. Print.

Wells, Stanley ed. Nineteenth-Century Shakespeare Burlesques. Vol. 4. London: Diploma Press, 1978. Print.

Wells, Stanley. Shakespeare For All Time. Oxford: Oxford UP, 2003. Print.

West, Shearer. "Shakespeare, Memory and the Visual Arts." In Hiscock and Wilder eds: 4661. Print.

Williams, Robert Folkestone. The Youth of Shakspeare. Paris: Baudry's European Library, 1839. Print.

Worrall, David. The Politics of Romantic Theatricality, 1787-1832: The Road to the Stage. London: Palgrave MacMillan, 2007. Print.

\begin{tabular}{l} 
Formatted: Font: Times New Roman \\
Formatted: Font: Times New Roman \\
\hline Formatted: Font: Times New Roman \\
\hline Formatted: Font: Times New Roman \\
\hline Formatted: Font: Times New Roman \\
\hline Formatted: Font: Times New Roman \\
Formatted: Font: Times New Roman \\
Formatted: Font: Times New Roman \\
Formatted: Font: Times New Roman \\
Formatted: Font: Times New Roman \\
Formatted: Font: Times New Roman \\
Formatted: Font: Times New Roman \\
Formatted: Font: Times New Roman \\
\hline Formatted: Font: Times New Roman \\
\hline Formatted: Font: Times New Roman \\
\hline Font: Times New Roman \\
\hline Formes
\end{tabular}

Formatted: Font: Times New Roman

Formatted: Font: Times New Roman

Formatted: Font: Times New Roman 